\title{
Some aspects of geographic views on motivational factor the tourist movements: the case northeastern Montenegro
}

\author{
Goran Rajović ${ }^{1, *}$, Jelisavka Bulatović ${ }^{2, * *}$ \\ 1 Street Vojvode Stepe 252, Belgrade, Serbia \\ Phone: 0038161/19-24-850 \\ 2 Department of Technology and Management, The College of Textile Design, \\ Street Starine Novaka 20, Belgrade, Serbia \\ Phone: 003861/3082651 \\ *,**E-mail address: dkgoran.rajovic@gmail.com , jelisavka.bulatovic@gmail.com
}

\begin{abstract}
The paper presents some aspects of geographical view of the motivational factor tourist movements in northeastern Montenegro on example, the municipality Berane, Andrejevica and Plav. Bjelasica, high mountain range Komova, spatial zone Berane and Mountain system Prokletija providing opportunities for development of various types of mountain tourism, such as the sports and recreation, health, summer pasture, hiking, hunting, fishing ... As another important group of attractive values of, appear attractive and social factors, which allow the counted among the following elements: cultural and historical monuments, cultural institutions, various cultural events ... Significant cultural and historical heritage of this part of north-eastern Montenegro, not yet adequately valorized. In order to achieve desired economic growth, change, renewal and improvement of the overall economy, it is understood and tourism, it is appropriate and adequate conception of development strategies. Assessment of the state of tourism is a prerequisite for defining the development goals, which fit into the overall vision of progress and active involvement in the immediate environment and the wider European mainstream.
\end{abstract}

Keywords: Northeastern Montenegro; tourist motifs; mountains; socially of attractive values

\section{INTRODUCTION}

Northeastern Montenegro abounds in natural beauties, which are the true small world treasure. Unfortunately, the potential of these natural treasures are small and under-used. Fairly well-preserved natural values in the tourist zone the researched the geographic space: Bjelasica, high mountain range Komova, spatial zone Berane and highland areas Prokletija with picturesque valleys of the rivers provide opportunities for the development of various types of mountain tourism, such as a sports and recreation, health, summer pasture, hiking, hunting, fishing ... [1].

Observing the market analysis conducted in Montenegro 2008 year stipulates is vacation in mountainous regions popular throughout the year. Reason going the mountain is the need for rest, relaxation, and stay at a healthy and clean air, the desire for recreation, skiing... The existing resources of northeastern Montenegro, its topography, lush vegetation, fresh air, 
healthy food, suggests that it has a number of resources related to cultural and natural heritage, which only should be used.

With the implementation of plans to improve conditions for tourism development in this locality began between alia the construction of ski runs and ski lifts, hotels and ethnic villages as well as other supporting facilities. The cause of the small number of tourist arrivals (the average length of stay of tourists in the year 2003 amounted to 3.10 days) and overnights (of the total number overnight stays in 2003 realized 10,034) lies in an undeveloped and insufficient number of accommodation facilities, as well as their low use.

Here in this place mention and confirming the Dulčić [2] tourism development plans at regional or local level should start from the following principles: tourism development is based on the development goals and priorities who determines locally resident population; should be considered the tourist market impulses, and the results of studies of tourism demand in its territory; development should be coordinated with of other development plans, not tourist activities should take into account the physical and visual, it is aesthetic appearance location thereby what they will not build inappropriate facilities and / or unacceptable conduct activities; in other words, has to be performed assessment of reception capacities of the site because, in its physical, social and economic opportunities.

\section{RESEARCH METHODOLOGY}

The core methodological procedure that was used in this study is the geographic (spatial) method. Thus, the study of geographical method was related to some aspects of geographical view of the motivational factor tourist movements in northeastern Montenegro. Northeastern Montenegro is a geographic unit, which includes $10.8 \%$ of the total area of Montenegro $\left(13.812 \mathrm{~km}^{2}\right)$. It includes three municipalities: Plav, Andrejevica and Berane [3,4]. For of data collection relating to basic characteristics of tourist zones as well as social factors are considered attractive geographic space, we used a comparative method.

Through the full text is Permeated the and method of integrity, thanks to which we are have managed to recognize, define and evaluate potential limitations to development of tourism. Historical method gave us the opportunity to look anthropogenic tourist values, respectively that based on historical findings reconstruct anthropogenic tourism potential of the region, among which are: monumental heritage, ethnographic characteristics cultural and art manifestations. For of data collection relating to tourism to the region, we used the statistical method, i.e. the data of the Statistical Office of Montenegro [5].

The research methodology is primarily based on an analysis of existing literature on the hotel industry, catering and anthropogenic tourist values northeastern Montenegro. Of the existing literature was used both domestic, as well as published in the international literature. On this occasion of the international publications emphasize this: Martín and Belén [6], Lam and Hsu [7], Zhang and Marcussen [8], Konu and Laukkanen [9], Becken and Hay [10]. Were studied and written sources on the internet. In scientific explanation of terms, we applied the two methods: analytic and synthetic. Analytical methods were considered some of the dimensions research subject. Synthetic method - a whole, are interrelations between objects and suggested measures deriving there from [11-13]. 


\section{ANALYSIS AND DISCUSSION}

Tourist motive is all what attracts tourists to a destination. It used to be only one motive, and sometimes groups of motifs. The journey to Hsu et al [14] consists of the points of departure times to the desired point and the destination itself, making the "travel system". Those destinations and companies that set the latest trends in tourism to the Marton-Lefevre and Borges [15], will certainly gain a competitive advantage. Lew [16] proposes a classification of all the tourist attractions based on three approaches:

1. Ideographic approach - represents systematization tourist attractions shaped the image of nature. It is most commonly used systematization of tourist attractions and is mainly used in studies that include small areas of study,

2. Organizational approach - an approach that systematize the tourist attractions in the surrounding area, the capacity of attraction, and the duration attractions and

3. Cognitive approach - systematize tourist attractions based on experiences and perceptions of tourist-related tourist attractions.

According to Lipman and Vorster [17]: "It is necessary to transform" classic tourism " by which dominated by considerations of growth and market share in the "smart tourism" that is inclusive, clean, green, ethical and customer-oriented and quality ". And just, in our example, this is the example of north-eastern Montenegro, in terms of tourist motivation and destination attractiveness, we highlight the mountain.

As another important group of attractive values, appear attractive and social factors, in which are considered one of the following elements: cultural and historical monuments, cultural institutions, many cultural manifestations...? Travel trends by type of motifs in this part of north-eastern Montenegro, are divided more of: urban, rural, event, river, lake, hunting and landscape. However, they are not the subject of this paper. Given that they had already found its place in the research activities of numerous authors. Among them this opportunity to emphasize this: Knežević [18], Kasalica [19], Kićović [20], Bakić [21].

Purpose of better of understanding of tourist valorization of the mountains in the observed geographic space, a more realistic picture is obtained if the serve the study of Nikolic [22]. By Nikolić [22], the observed geographic space tourist to highlight the following areas: Bjelasica, high mountain range Komova, spatial zone Berane and highland areas Prokletija.

Bjelasica represents small, very homogeneous mountainous tourist region, strictly limited to the Lim river mountain pass Trešnjevik. This is an area of high tourism opportunities, especially for winter sports activities and summer recreation. According to the significance behind Durmitor, although the degree of tourist attractions tourist region in the developing world. The appeal is based on a variety of natural - motif units (national park "Biogradska mountains", Small and Big Šiško, Small and Big Ursulovačko, Pešić lakes).

High mountain range Komova is morphologically quite isolated tourist micro region. Komovi are gigantic mountains, of the highest degree attractiveness of its verticals seem overwhelmingly and challenging for planning and nature lovers. The mountain is rich in vegetation, wildlife, water skiing terrain, but relatively well open to traffic (Plav - Andijevica - Mateševo -Podgorica), which represents the shortest travel route, but not the best. In the immediate neighborhood of her tourist complex and ski valuable Bjelasica, Visitor and Prokletije, and it lags behind in tourism fair valuation of these mountains. Therefore Komove should be preserved as an important ecological, hydrological, and potential for the future. 
Their activation tourist would, for this reason, should move gradually through rural tourism, hunting and hiking, and under the influence of tourism development of neighboring regions.

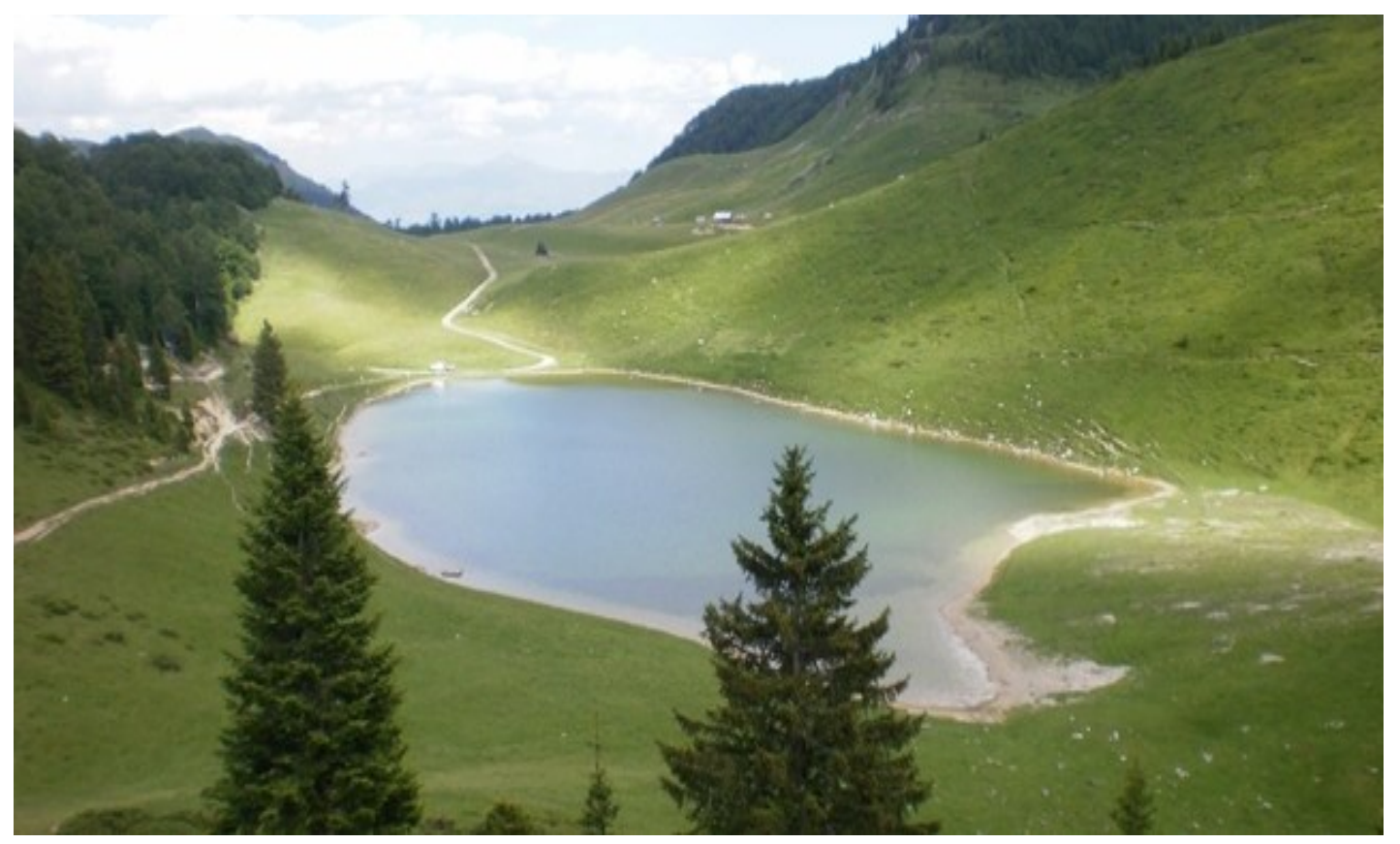

Figure 1. Bjelasica - View on Šiško Lake [23].

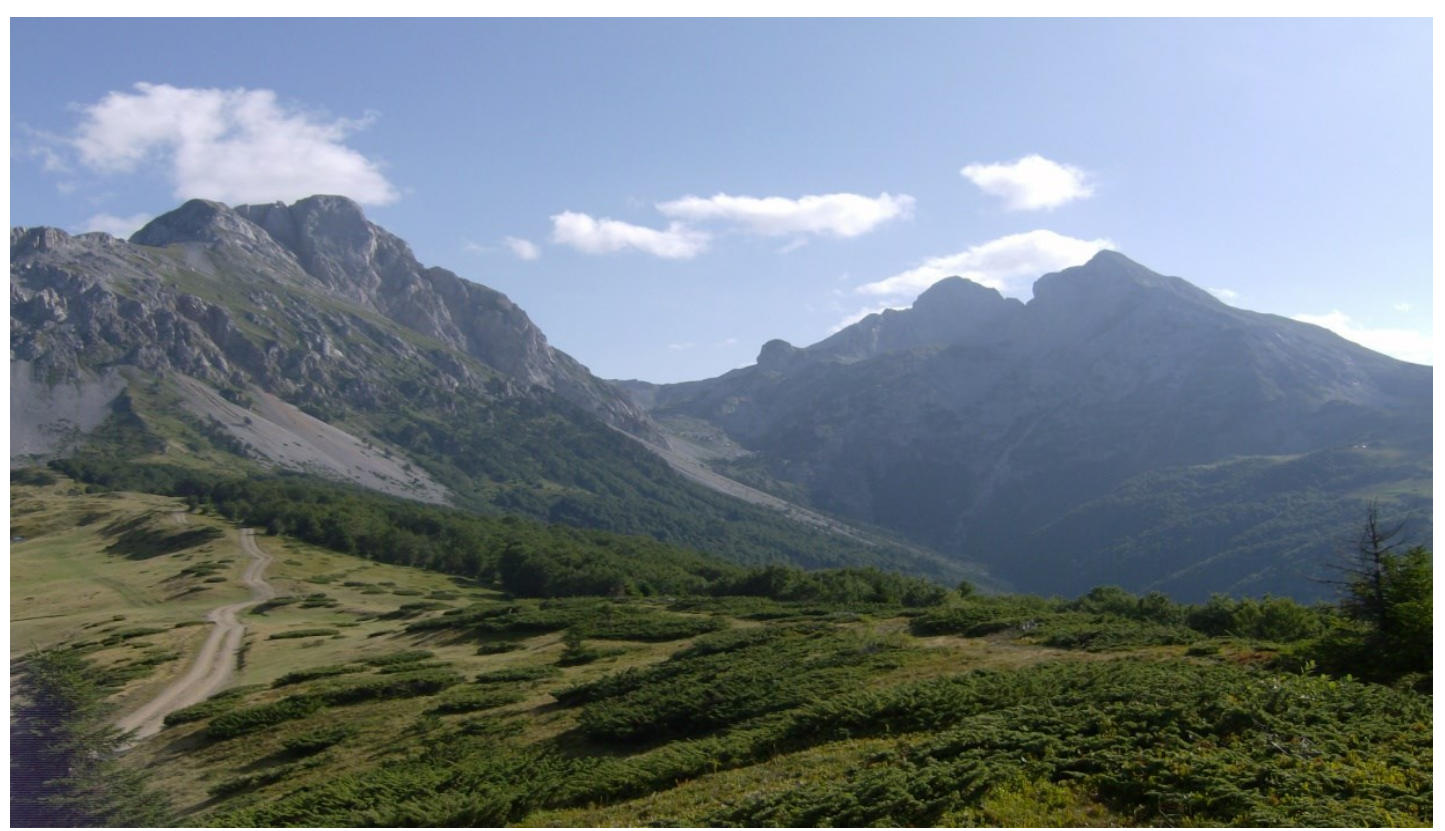

Figure 2. Vehicular traffic - easy arrive to the foot Komova [24]. 
Tourist zone Berane, covers parts of different spatial units, each functionally related. It is made up of valleys Berane and mountains Cmiljevica. It is characterized by rich forest ecosystems, landscapes, convenient ski area in terms of the development of rural tourism. Functional connectivity of the area provides the continental part of the Adriatic Highway with transit traffic. And Berane in this zone gets the tourist office, due to transit traffic and the road through the valley of Lima, as the role of logistics support and the holder of the material basis of tourism development of the area, but also over the role of tourism in the mountainous part of Bjelasica.

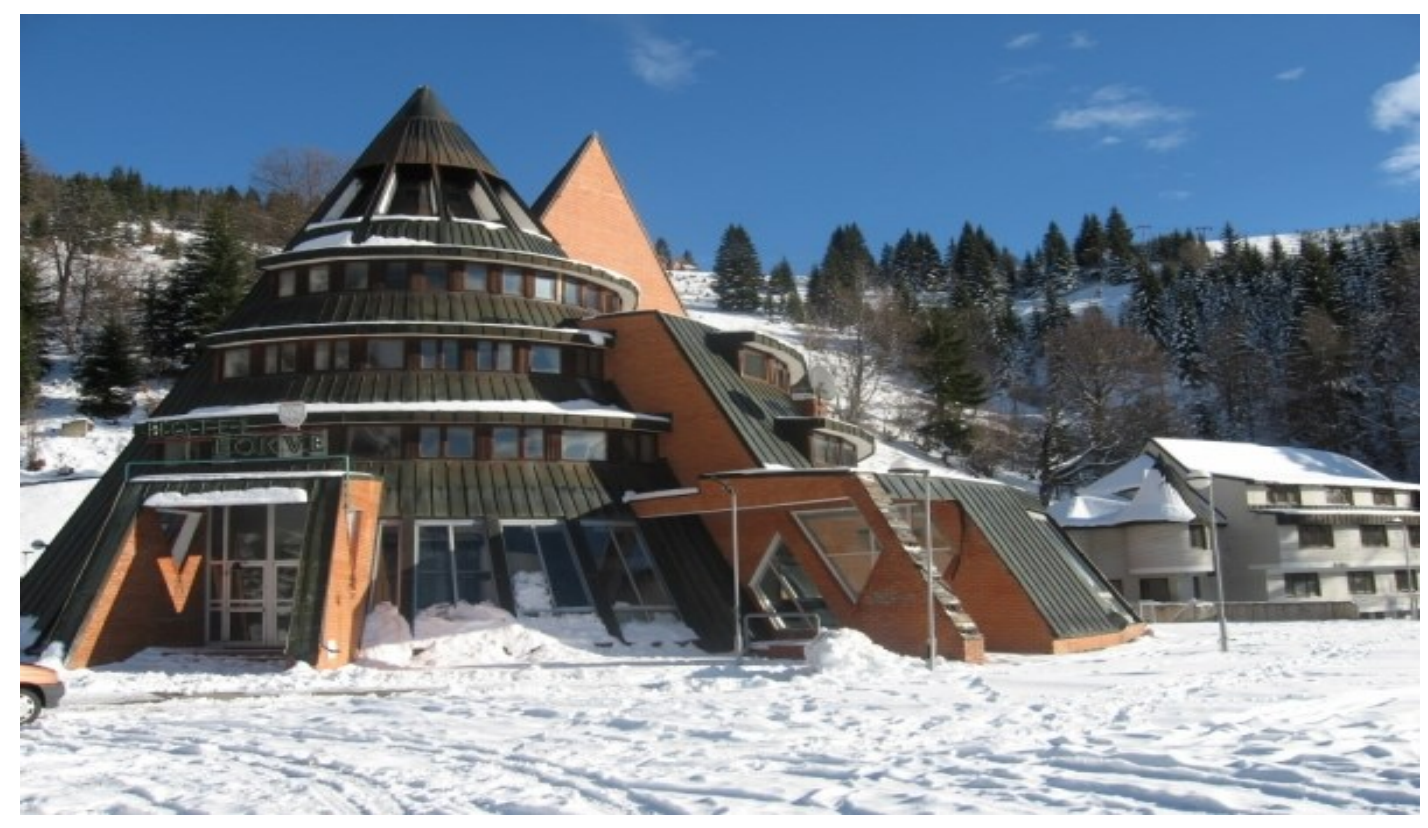

Figure 3. On the mountain Cmiljevica - findings the ski Center Lokve [25].

Mountain Prokletija system has very high tourism value and practical conditions for the organization of tourism in today's conditions, very little for transportation and border restrictions. Therefore it is possible to make reservations as ecological potential of the national park and gradually activated in peripheral areas (Prokletije been declared a national park in 2009). Part Prokletija can be activated in the development of the observed geographic space; a closer can be defined as Plav - Gusinje tourist region called Prokletiije shell. Its basis consists of Plav Lake and Valley Ljuča, and enclosing a mighty mountain ramparts Visitor and Prokletija, with great opportunities for all kinds of mountain tourism, and the first initiative will be the center of winter tourism massif Bor - Kofiljača. Therefore, this is a functionally complete touristic spatial unit with excellent opportunities for the development of recreational summer and winter sports tourism, but only at the beginning of tourism development, which will require a great investment for winter ski sports.

As another important group of attractive values in this part of north-eastern Montenegro, appear attractive social factors, in which are considered one of the following elements: cultural and historical monuments, cultural institutions, many cultural manifestations, and various anthropogenic factors? Cultural and historical monuments, in fact, material wealth and reflects the achieved level of development of the culture of the considered geographic space. 


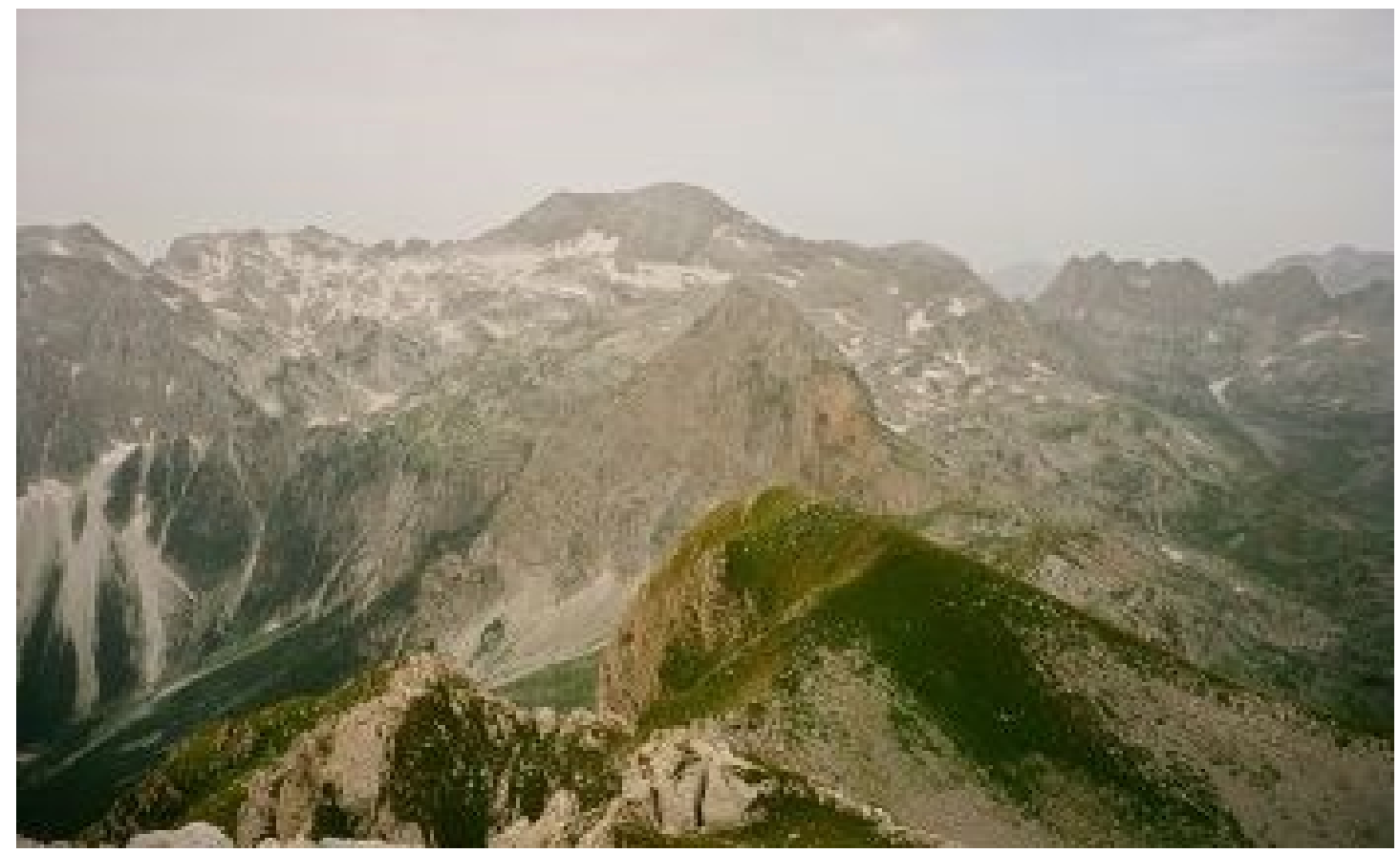

Figura 4. Prokletije - View with Maje rosit [26].

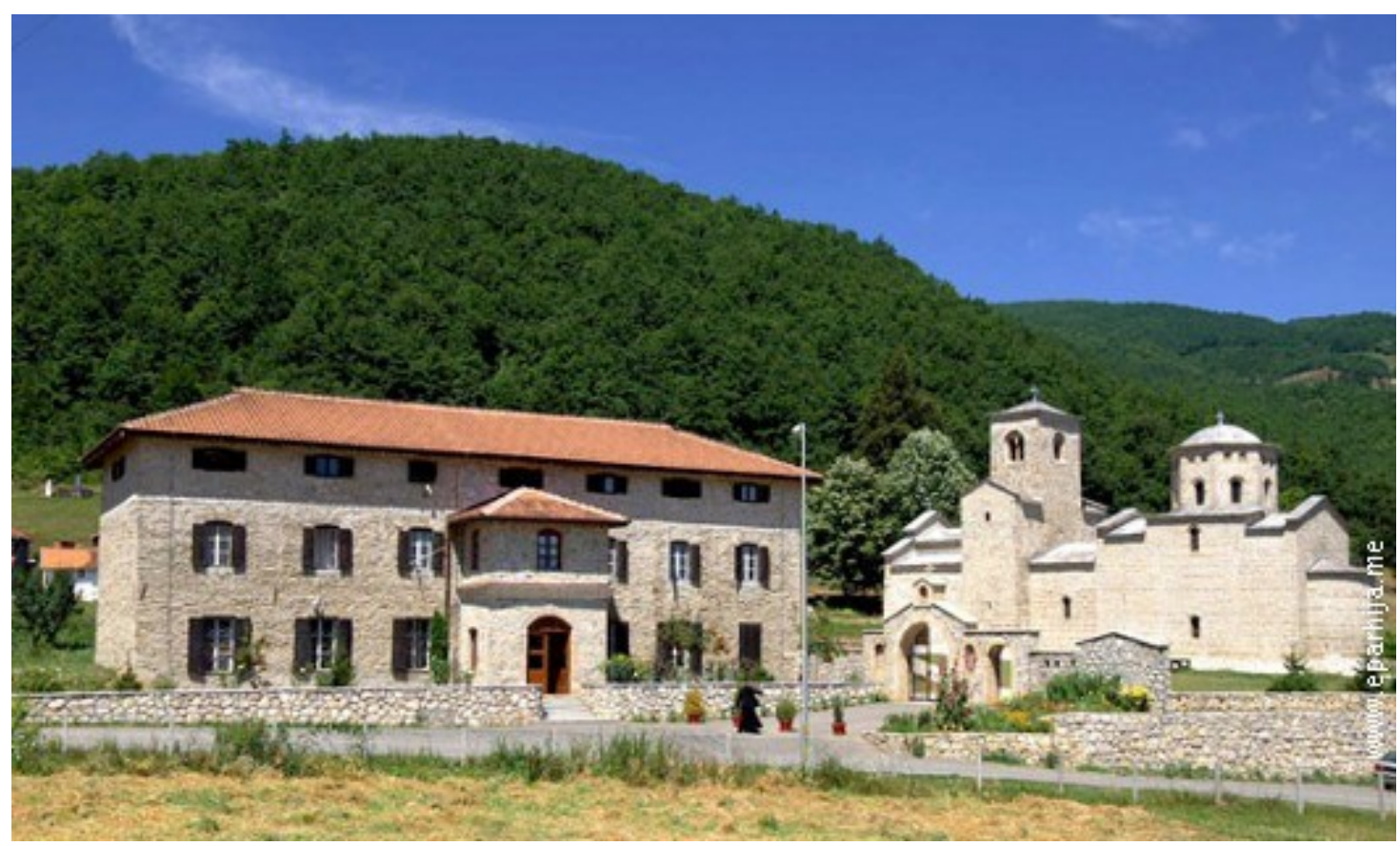

Figure 5. Monastery Đurđevi Stupovi with Berana- 2013 celebrated 800 years of existence [28].

A special group of tourist motives make the monuments of medieval church architecture (Đurđevi Stupovi monastery, the remains of the monastery Šudikovo, the church of the St. Archangel, the church of the Holy Trinity) and remains of the medieval fortress (Plav, Bihor ...). In Sudikovi, the Church Presentation of the Holy Virgin Mary founded one of the earliest written documents from these parts - "Holy-Proceedings"("Trojica"). Modest part of the 
monumental heritage of waste is on Islamic Architecture (Redžepagić mosque, mosque Ferovića, Vizirova, Pašića and Čekića mosque ...) [27]. In the region, there are today many and diverse memorial features (monument Knjaževac, memorial - complexes in Andrijevica, Berane and Plav and many others across the region erected a memorial plaque, memorial statue, memorial fountains ...).

According Kasalica [19], the material and spiritual wealth of people present in the northeastern part of Montenegro from the earliest times to the present, carries a significant part of the ethnographic heritage, created under the influence of various civilizations, cultures and their own cultural skills. We note from this group content (various parts household items, dishes, fabrics, parts of the costumes, tools for agricultural production, jewelry and weapons, sacral object ...), folklore of music (folk songs and dances), traditional gatherings for many reasons have the character of tourism events, it is providing an opportunity for the presentation of ethnographic heritage.

At the same time, a variety of cultural institutions, as well as various events of local, national importance of its contents contribute to the overall satisfaction of tourists and complement the content of their stay. Precisely reflects the special role of events in contemporary tourism. Manifestations are a global phenomenon that is gaining importance in industry events. The importance of manifestation is through the preservation and promotion of the traditions and cultural heritage, source of income, effective as a means of attracting foreign and domestic tourists a great opportunity to engage local resources, contractors, and an excellent resource for the promotion of destinations, local culture and social values. In the considered region, tourist manifestation is modest.

This is primarily we mean to the following: Lim regatta, Days blueberries and honey, Gusinje summer, Days of diaspora, Horse racing Vusanje, Plav literary meetings, Homeland meetings, Memorial tournament, "we will not never forget your, " Sculpture and art colony, "Jumps for unforgettable", Days Watermelon, Days chokeberry, Days "Behara", Andrijevica days of culture, Days of Red Cross, the International Folklore Festival, Memorial Vasojevićkog Koma, St. Vitus a poetic vigil, Berane cultural summer, Common wedding, Ivangrad Fest, Days float, Days of honey, The fair of agricultural products. One of the main features of manifestation is to will remain memorized as a unique experience for all visitors.

Of the institutions involved in culture we highlight "Cultural Centre" in Berane. The program of the institution is carried out through activities cinemas, theaters, art workshops, music and other programs. A large number of programs carried out in cooperation with schools. Some of these programs are: Berane summer, Berane spring, reciting competition, writers... When it comes to fine arts (drawings, watercolors, oil paintings and other works of art), usually are saved in Museum Polimlje in Berane.

Musical and theatrical productions of the studied region, however, have not yet crossed the borders of amateurism. In addition to several cultural and artistic societies (CAS "Dušan Bošković" in Beranama, CAS "Bihor" in Petnjica and CAS "Džafer Nikočević" in Gusinje) and experimental drama scene who works at the Center for culture in Berane almost no shape for that aforementioned artists and music styles directed by and to stage set.

Recognizing the importance of this factor in the development of tourism with its economic, as well as the broader social and political importance, a large number of regions, as, after all, I considered, given the increasing importance. Recognizing tourist motives, not enough for are left to the elements and poor organization. 


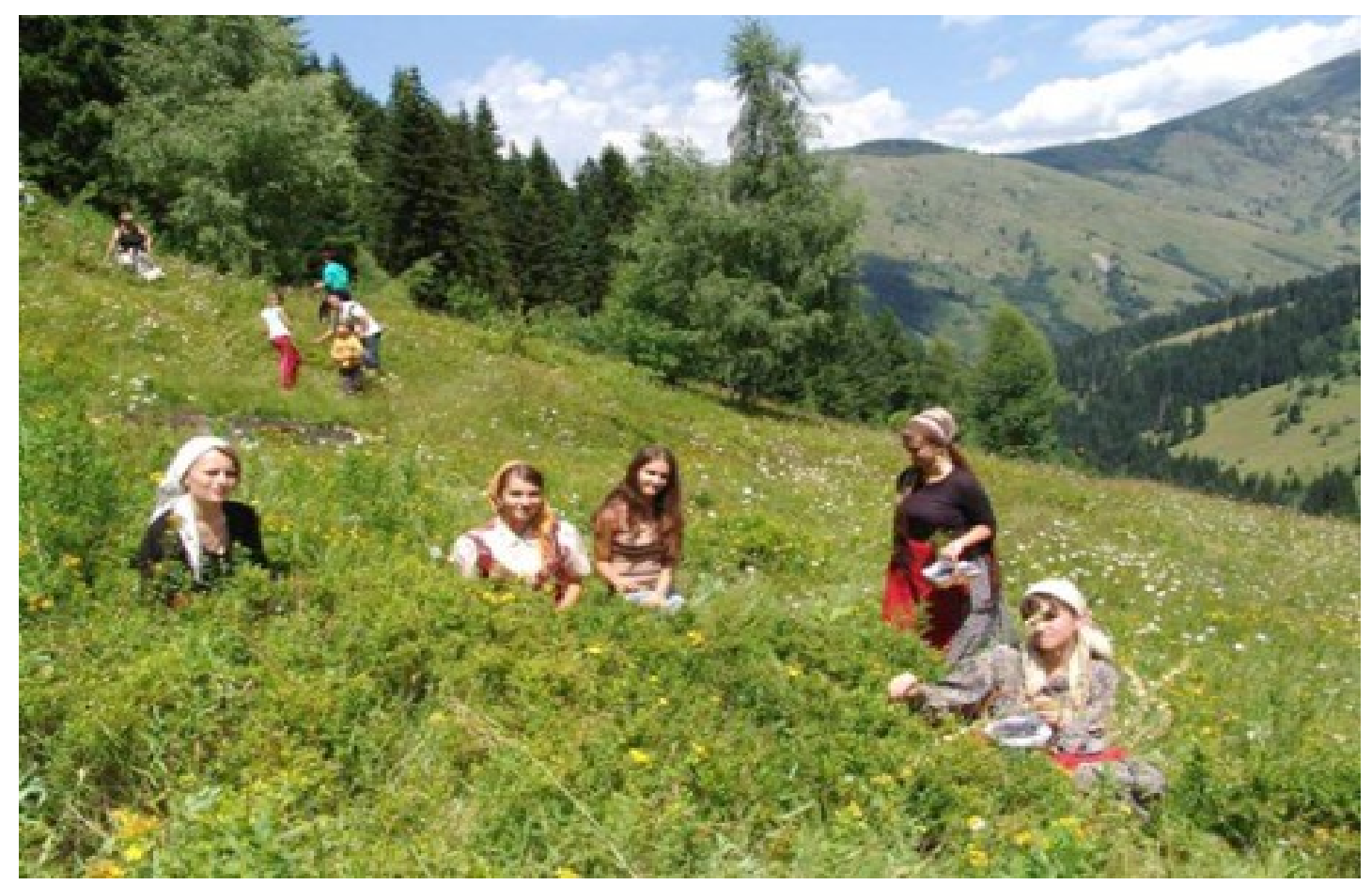

Figure 6. Days of blueberries municipality Plav - are held each year (month of July) [29].

On the contrary, these factors should certainly incorporate the contents of a tourist's stay, the more they gain in importance. According to Cooper et al [30] and Buhalis [31], the majority of tourist destinations are an amalgamation of the following components:

1. Attractions-imply natural and social attractiveness are important to ensure the initial motivation of tourists for coming to destination,

2. Amenities - comprise accommodation and restaurants, shops, entertainment and other services,

3. Accessibility - refers to the development and maintenance of effective transport links to the source markets (international transport terminals and local transport),

4. Available packages - include the previously prepared package arrangements by an intermediary in the sale and their representatives,

5. Activities - apply to all activities available in destination and what is important to consumers during their stay in the destination and

6. Ancillary services - include the marketing, development and coordination of activities carried out by certain organizations a destination for consumers and industry.

For the needs tourism in these areas, they can build a healthy tourist home Milenković [32], which would have the following purposes:

1. For purposes of sport fishermen and their rest and recreation,

2. Type hunting lodge tourist homes for year round hunting season, the organization of horse games hilly and mountainous horse,

3. For tourist manifestation, such are mowing meadows, which has recreational and competitive character,

4. For picking of medicinal plants and their presentation to tourists, with the possibility of tasting and purchase, 
5. For camping and picnics,

6. For the exhibition and fairs of livestock products and handicrafts for tourists,

7. For tourist manifestation with traditional folk custom (selection most beautiful shepherdess, embroiderer, knitters ...), and

8. For sports and recreation purposes.

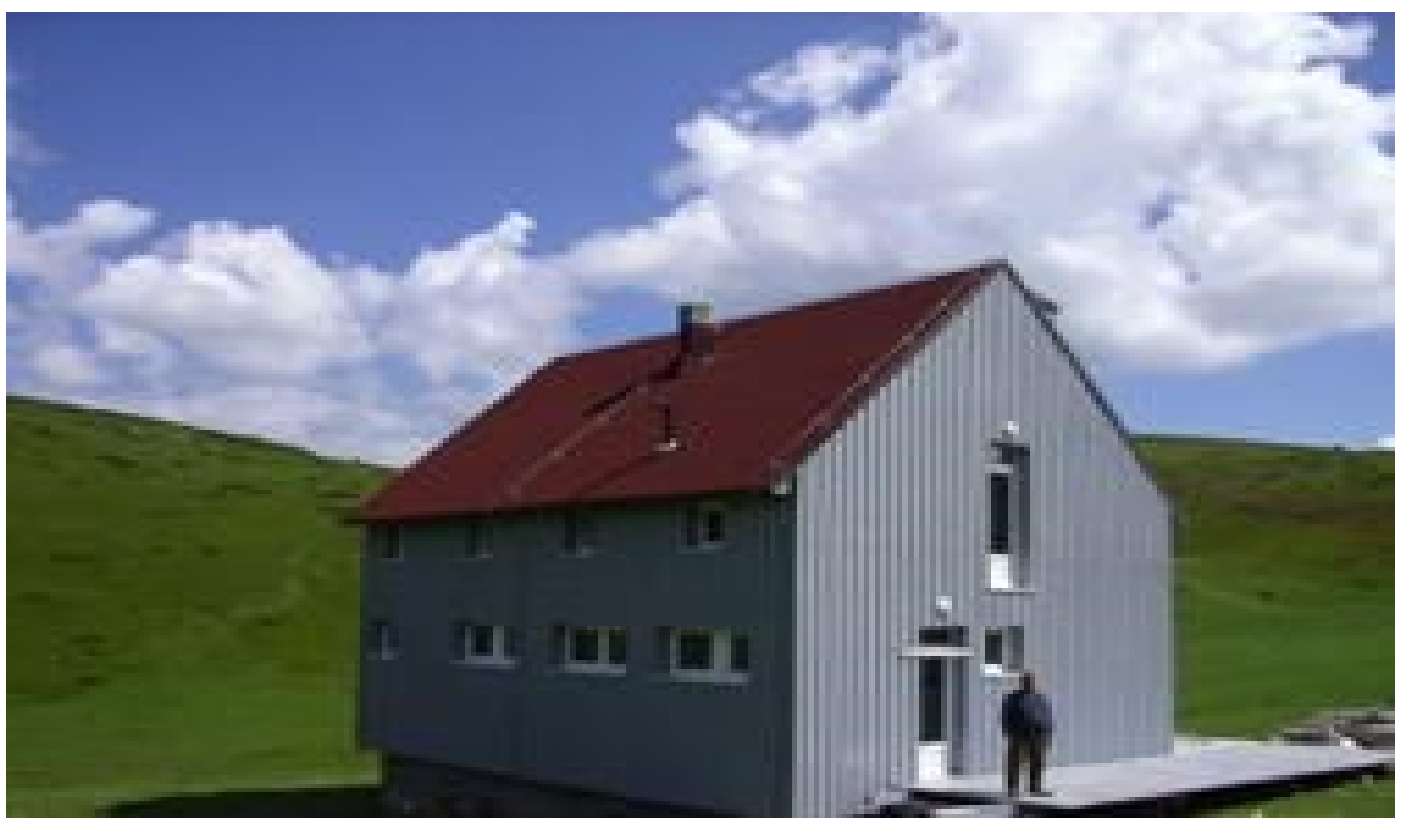

Figure 7. Mountain Krivi do - mountain hut (municipality Andrijevica) [33].

Every good tourist organized household, may develop special forms of tourism, including the most common: the accommodation of guests within its own grounds offer of its own products, bids from your own kitchen, offer drinks from their own cellar, degustation wines and spirits, organizing trips for the environment, camping on the property, a temporary one-day visit to groups up to 50 people...

\section{INSTEAD CONCLUSION}

The tourist-geographical analysis is not always easy to distinguish how much in missed opportunities have a participation objectively presence limiting conditions (mountains in the considered geo-space), and how they must attributed to insufficient or inadequate economic organization and incomplete information [34].

Previous program of tourism development are respected specific geographical conditions in this part of north-eastern Montenegro, therefore could not provide adequate results. In order to accomplish the desired economic growth, change, renewal and improvement of the overall economy, it is understood and Tourism must have corresponding and adequate conception of development strategies. Assessment of the state of tourism northeastern Montenegro prerequisite for defining the development goals, which fit the vision general progress and more active involvement in the immediate surroundings and the wider European mainstream [35]. 
Thus, by Weaver [36] Sustainable tourism should:

1. Make optimal use of natural resources are a key element in tourism development, maintaining essential ecological processes and helping to conserve natural heritage and biodiversity,

2. Respect the socio-cultural authenticity of host communities, protecting them built and contemporary cultural heritage and traditional values, and contribute to understanding and tolerance between cultures,

3. Provides a viable a long term business by creating socio-economic benefits that are fairly distributed to all stakeholders, including stable employment and incomegenerating opportunities and social welfare of host communities, and contributing to poverty reduction,

4. Maintain high levels of tourist satisfaction and provide valuable experience to tourists, raising their awareness about sustainability issues and promoting sustainable tourism.

Scheyvens [37] points out the basic parameters of training local communities in tourism development, which would definitely able to find place on the territory of the municipality Berane Andrijevice and Plav. So the above is the author distinguishes type I signs to make local communities for tourism development. The type of training includes: economic, psychological, social and political empowerment.

The economic empowerment of local communities in tourism development, are noticeable by Scheyvens [37], the following signs of training - tourism brings long-term financial benefits destination. The money is spread within the community. Improving local services and infrastructure are noticeable. The psychological meaning empowering local communities in tourism development are noticeable following signs of training - for extreme self-confidence is growing recognition of the uniqueness and the vault is their culture, natural resources and traditional knowledge. The growing confidence in the local community and will seek opportunities for further education and training. Access to jobs and money, improve the social status of the population, whose status is normally low, such as in particular women and young people. The social importance of training local communities in tourism development, are noticeable following signs of-tourism training speeds up the balance of the local community and contribute to its establishment. The correlation of local community because. Individuals and families work together to develop a successful business. Some funds are used to development initiatives in the community, such as those related to education and road construction. The political importance of training local communities in tourism development are noticeable following signs of training and political structure of the community is the representative forum where people can ask questions and discuss problems related to tourism initiatives. Agency who initiate or establish tourism enterprises seek the views of stakeholders and members of the community, and provide them the opportunity to participate in decisionmaking bodies.

Anyway, every good travel organized household, especially in the rural northeastern part of Montenegro may develop a certain forms of tourism, including the most common: accommodate guests on own farm, offer their own products, offer the own kitchen, offer drinks from their own cellar, tasting wines and spirits, organizing trips for the environment, camping on the land, occasional services for a one-day visit to the group of 50 people...

Overall business and tourism development philosophy of the modern age, the maximum is geared towards tourists, guests and consumers and its satisfaction. The modern consumer knows exactly what wants and regions that want to be successful, as it after all analyzed, have a the primary task is to identify the client's needs and find creative ways to meet them. Services 
should be everything better and standards of equipment ever higher. Guest looking for all in one place: quality, safety and comfort.

\section{References}

[1] Rajović G., Bulatović J., Journal of Energy and Natural Resources 2 (2) (2013) 7-20.

[2] Dulčić A., Management development tourism, Mate d.o.o., Zagreb, 2001.

[3] Rajović G.,Bulatović J., International Letters of Social and Humanistic Sciences 6 (2013) 24-35.

[4] Rajović G., Journal of Road and Traffic Engineering 58 (2) (2012) 63-68.

[5] Statistical Office of Montenegro (2004). Census of Population. Podgorica.

[6] Martín G., Belén M., Annals of Tourism Research 32(3) (2005) 571-591.

[7] Lam T., Hsu C. H., Tourism Management 27(4) (2006) 589-599.

[8] Zhang J., Marcussen, C., Tourist motivation, market segmentation and marketing strategies. In 5th Bi-Annual Symposium of the International Society of Culture, Tourism, and Hospitality Research, Charleston, South Carolina, 2007.

[9] Konu H., Laukkanen T., Journal of Hospitality and Tourism Management 17(1) (2010) 144-149.

[10] Becken S., Hay J. E., Climate change and tourism: From policy to practice, Routledge, 2012.

[11] Rajović G., Journal Montenegrina (Natura Montenegrina) 5(2006) 161-168.

[12] Rajović G., Bulatović J., Russian Journal of Agricultural and Socio - Economic Sciences 4(16) (2013) 35-45.

[13] Rajović G., International Letters of Social and Humanistic Sciences 11 (2013) 35-46.

[14] Hsu, C., Killion L., Brown G., Gross M.J., Huang S., Tourism Marketing, an Asia-Pacific Perspective, John Wiley \& Sons, Australia, 2008.

[15] Marton-Lefevre J., Borges M.A., A New Big Plan for Nature: Opportunities for Travel \& Tourism. U J. Blanke \& T. Chiesa, The Travel \& Tourism Competitiveness Report 2011,World Economic Forum, Geneva, Switzerland, 2011.

[16] Lew A. A., A Annals of Tourism Research 4 (4) (1987) 553-575.

[17] Lipman, G., Vorster, S., Green Growth, Travelism, and the Pursuit of Happiness. U J. Blanke \& T. Chiesa, The Travel \& Tourism Competitiveness Report 2011, World Economic Forum, Geneva, Switzerland, 2011.

[18] Knežević M., Regions Plav-Gusinje-Conditions for the development of tourism, Serbian Geographical Society, Book 50, Belgrade, 1979.

[19] Kasalica S., Northern Montenegro, University word, Nikšić, 1988.

[20] Kićović M. D., Tourism and nature protection Upper Polimlja, University word, Nikšić, 1995. 
[21] Bakić R., Upper Polimlje : nature, population and settlements, Nikšić : Geographical Institute of Philosophy Faculty; Andrijevica: Publishing house Komovi, (2005).

[22] Nikolić S., Nature and Tourism of Montenegro, Institute for Protection of Nature, Podgorica, 2000.

[23] Mountains Bjelasica- Excursion, Available from: http://www.ramstravel.co.me (16.09 2013).

[24] Rajović G., Bulatović J., Anuario Turismo y Sociedad 13(2012) 171-184.

[25] Mountains Cmiljevica - Ski Center Lokve (Berane), Available from: http://www.skijanje.rs (15.09 2013).

[26] Mountains Prokletije - Excursion, Available from: http://www.putokaz.me (16.09 2013).

[27] Mijović P., Viewing art Montenegro, In Monograph Montenegro, Literary Gazette, Belgrade, (1976).

[28] Monastery Đurđevi Stupovi in Berane, Available from: http://www.eparhija.me (28.08 2013)

[29] Blueberry - black gold, Available from: http://www.gusinjefuondation.info (31.08 2013)

[30] Cooper C., J. Fletcher S., Wanhill D., Gilbert, R., Shepherd, Tourism Principles and Practice Essex: Pearson Education, 1998.

[31] Buhalis D., Tourism management 21(1) (2000) 97-116.

[32] Milenković R. S., Yearbook of the Faculty of Economics in Kragujevac 175-185 (1998).

[33] Municipality Andrijevica, Available from: http://www.andrijevica.me (04.09 2013)

[34] Rajović G., Journal industry 39(3) (2011) 261-280.

[35] Rajović G., Bulatović J., International Letters of Social and Humanistic Sciences 6 (2013) 49-61.

[36] Weaver D., Sustainable Tourism: Theory and Practice. Butterworth-Heinemann, Oxford, 2006.

[37] Scheyvens R., Tourism management 20(2) (1999) 245-249. 